\title{
Main Biogas Upgrading Technologies
}

\author{
Paulo S Domingues ${ }^{1 *}$, Helena Pala ${ }^{2}$ and Nelson S Oliveira ${ }^{2}$ \\ ${ }^{1}$ School of Technology and Management (ESTG), Polytechnic Institute of Leiria, Portugal
}

${ }^{2}$ Laboratory of Separation and Reaction Engineering-Laboratory of Catalysis and Materials (LSRE-LCM) \& School of Technology and Management (ESTG), Polytechnic Institute of Leiria, Portugal

Submission: March 02, 2021; Published: April 05, 2021

*Corresponding author: Paulo S. Domingues, 1School of Technology and Management (ESTG), Polytechnic Institute of Leiria, 2411-901 Leiria, Portugal

\section{Abstract}

Biogas is a combustible gas mixture, and its chemical composition depends on the conditions on the production unit. Biogas can be valued thus constituting a renewable energy source. This review article provides a comparative analysis of the main technologies used in the treatment and purification of biogas. Treatment methods, such as $\mathrm{H}_{2} \mathrm{O}$ and $\mathrm{H}_{2} \mathrm{~S}$ removal processes from biogas are described. After treatment, biogas can be used directly to produce thermal and electrical energy. Biogas upgrading is possible through its purification, obtaining biomethane that can be used as a substitute for natural gas. This review article also highlights the main technologies for biogas purification through $\mathrm{CO}_{2}$ removal processes. Among the various biofuels, biomethane is a versatile fuel, and is expected to play an essential role in the circular bioeconomy. The advantages and disadvantages associated with each of these biogas treatment and purification technologies are also discussed.

Keywords: Biogas; Biomethane; Purification; Carbon dioxide; Hydrogen sulfide

\section{Introduction}

Biogas can be produced in landfills and anaerobic digestion units. It results from the release of gases when an organic waste is decomposed in the absence of oxygen [1]. Biogas can also be produced through thermal pyrolysis and gasification processes.

This gas mixture consists of $40-75 \%$ methane $\left(\mathrm{CH}_{4}\right), 25-55 \%$ carbon dioxide $\left(\mathrm{CO}_{2}\right)$ and other constituents or impurities in small amounts, such as hydrogen $\left(\mathrm{H}_{2}\right)$, oxygen $\left(\mathrm{O}_{2}\right)$, nitrogen $\left(\mathrm{N}_{2}\right)$, hydrogen sulfide $\left(\mathrm{H}_{2} \mathrm{~S}\right)$, water $\left(\mathrm{H}_{2} \mathrm{O}\right)$ and ammonia $\left(\mathrm{NH}_{3}\right)$ [2]. It also contains dust particles, siloxanes, aromatic and halogenated compounds, although in very small quantities [3].

Biogas has a significant calorific value, so it has energetic value. The calorific value of biogas is calculated based on the percentage of $\mathrm{CH}_{4}$ considering that $\mathrm{CO}_{2}$ is an inert gas in terms of flame and occupies volume, negatively influencing the calorific value of biogas. $\mathrm{CH}_{4}$ is a colorless and odorless gas, which makes up a flammable mixture when added to air. It's a greenhouse gas that contributes about 21 times more to the effect, compared to $\mathrm{CO}_{2}[4]$.

The concentrations of impurities or contaminants present in the biogas depends on the source. The removal of $\mathrm{H}_{2} \mathrm{~S}$ from biogas is essential since sulfuric acid $\left(\mathrm{H}_{2} \mathrm{SO}_{4}\right)$ is formed in the presence of steam. This acid is extremely dangerous and corrosive to conventional engines, compressors and other mechanical materials [5].
Biogas can be used as fuel in boilers to produce heat and steam in different industrial applications. In this case, biogas utilization without any type of treatment is a technology with great reliability. However, to avoid corrosion problems, the $\mathrm{H}_{2} \mathrm{~S}$ level must be less than $1000 \mathrm{ppm}$. Mainly in developing countries, it is used for domestic application, for cooking food and lighting [3]. In co-generation facilities with internal combustion engines or gas turbines, biogas can be used to produce combined heat and power (CHP). In this process, a high-quality gas isn't required, however it is advisable to remove the water, avoiding its condensation in the pipes. The $\mathrm{H}_{2} \mathrm{~S}$ content must be less than $250 \mathrm{ppm}$ to avoid corrosion in the equipment. One of the main disadvantages for using biogas in this process is due to its low calorific value [2]. The reform of biogas in catalysts, instead of the reform of methane, is an ecological and economic method to produce hydrogen, allowing the reduction of $\mathrm{CO}_{2}$ emissions. However, it is necessary to remove the $\mathrm{H}_{2} \mathrm{~S}$ from the biogas, as it is harmful to the nickel catalyst. In this process, the formation of carbon monoxide (CO) as a gaseous by-product is a problem, with a content in the range of $50 \mathrm{ppm}$ acting negatively on the fuel cell. A viable solution for $\mathrm{CO}$ reduction is through controlled steam reform. Currently, hydrogen produced through biogas is used in cells, which efficiently convert hydrogen into electricity [3]. The injection of biomethane into the house- 
hold pipeline system for distribution is also a possible application. This upgrading is carried out through biogas treatment and purification processes, separating the $\mathrm{CH}_{4}$ from other components of biogas. Biomethane can thus be used as an alternative to natural gas from fossil sources [2]. The use of biogas as a vehicle fuel represents another method of recovery, although still with limitations, since a very high purification is necessary. Using appropriate technology, it is possible to replace a fossil fuel, normally used as Compressed Natural Gas (CNG) or Liquefied Natural Gas (LNG), with an equivalent biofuel. In addition to the removal of other gases, resulting in a content $\geq 97 \%$ of $\mathrm{CH}_{4}$, this biomethane can be compressed (Bio-CNG) or liquefied (Bio-LNG) for use as a vehicle fuel (Bio-VNG). The characteristics of this fuel allow an identical engine performance, compared to the use of fossil gas, thus it has enormous potential to become one of the most sustainable, economic and ecological vehicle fuels in the future [3]. According to Figure 1, biogas is used mainly in five different applications.

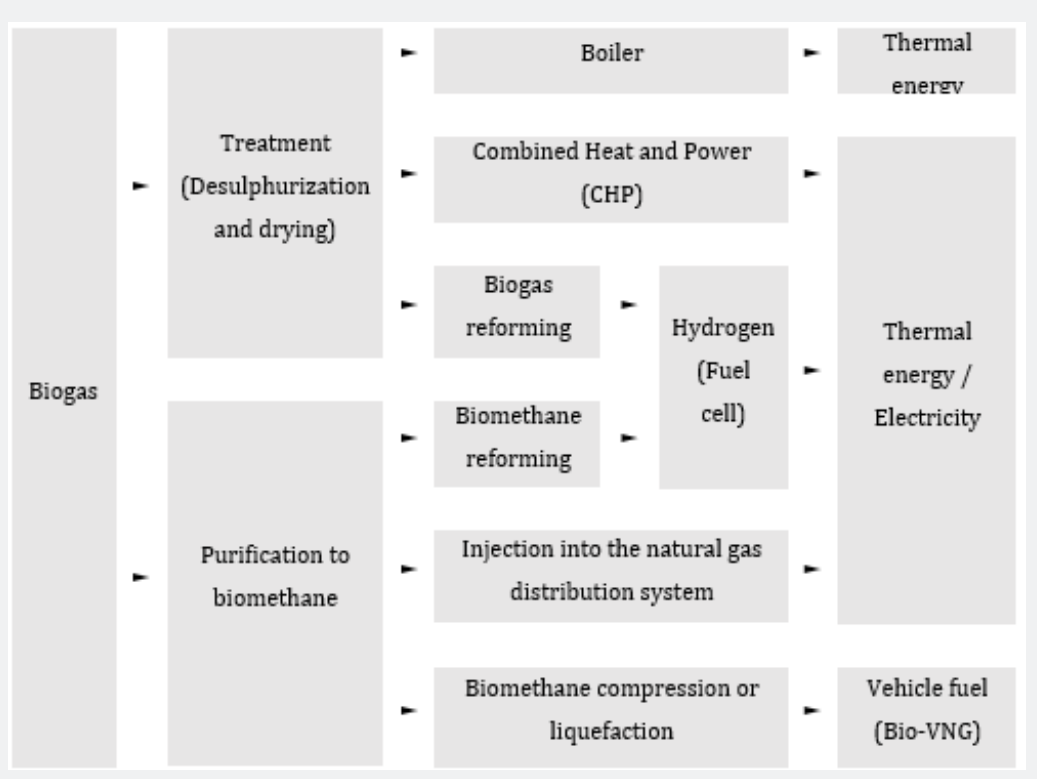

Figure 1: Main biogas potential applications

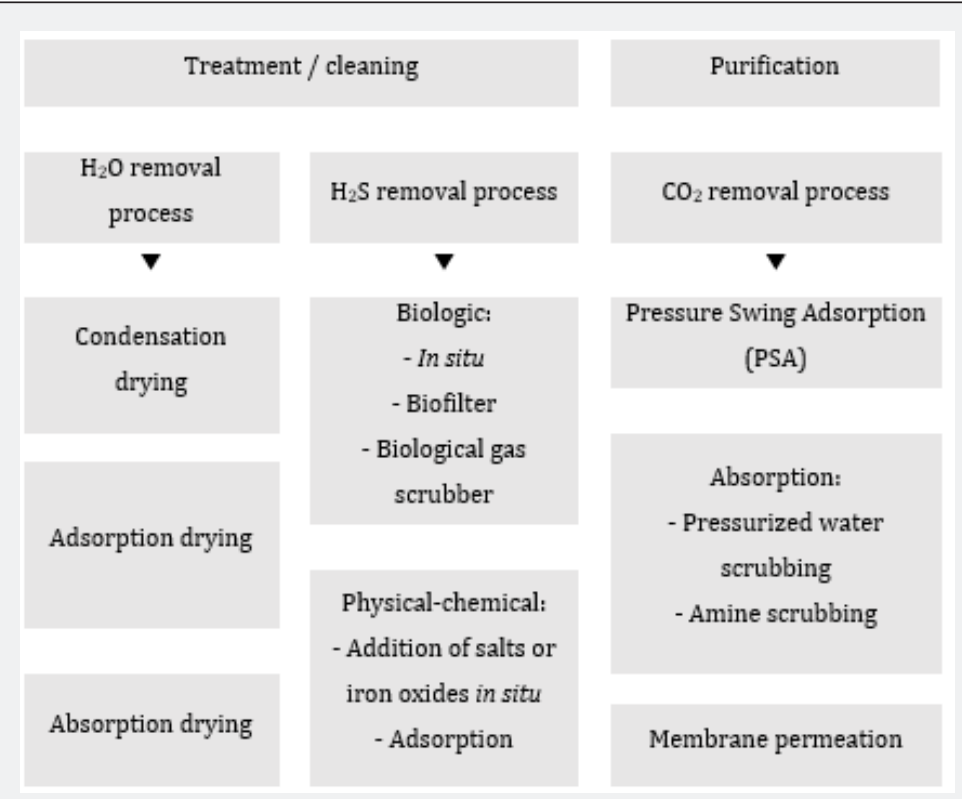

Figure 2: Main technologies to biogas treatment and purification

Controlling the level of impurities in biogas is essential to the success of its recovery. The implementation of treatment and purification technologies must consider the requirements of each specific application of biogas. These technologies aim to adjust the calorific value and remove contaminants that affect the quality of biogas and the useful life of the equipment. The most demanding 
techniques aim to purify biogas to obtain biomethane [6]. Currently, different techniques that allow the treatment and purification of biogas are commercially available (Figure 2).

The choice of the appropriate treatment and purification technology depends on factors such as the amount of biogas produced and its composition, the level of purification required and costs, namely capital and operational expenditure (CAPEX and OPEX) [3]. In biomethane requirements, a combination of processes is used, as no technology can remove all contaminants from biogas [1].

\section{Biogas Treatment}

When the aim is the biogas treatment without the degree of purification requirement for biomethane, simpler technology and less cost can be implemented, provided that the minimum requirements for this application are met [3]. Different processes that allow the treatment of biogas are commercially available, involving $\mathrm{H}_{2} \mathrm{O}$ and $\mathrm{H}_{2} \mathrm{~S}$ removal processes. In selecting the most suitable technology for the biogas treatment it is necessary to consider the amount of biogas to be treated and the initial concentration of $\mathrm{H}_{2} \mathrm{~S}$ [7].

\section{$\mathrm{H}_{2} \mathrm{O}$ removal process}

Biogas can contain a water concentration between 3 to $10 \%$. The water removal process is usually carried out at an early stage of the treatment, to protect the downstream equipment against corrosion. In addition, it allows to fulfill the requirements of subsequent purification steps [7]. Table 1 summarizes the advantages and disadvantages of biogas $\mathrm{H}_{2} \mathrm{O}$ removal processes.

Table 1: Advantages and disadvantages of the main $\mathrm{H}_{2} \mathrm{O}$ removal processes from biogas.

\begin{tabular}{|c|c|c|}
\hline Process & Advantages & Disadvantages \\
\hline Condensation drying & $\begin{array}{l}\text { - Simple process, suitable for any biogas flow; } \\
\text { - Elimination of hydrocarbons and oils particles; } \\
\text { - Application as pre-treatment in all systems. }\end{array}$ & $\begin{array}{c}\text { - High energy consumption; } \\
\text { - Requires installation of long tubes with slope and } \\
\text { freeze-resistant; } \\
\text { - High investment and maintenance costs. }\end{array}$ \\
\hline Adsorption drying & $\begin{array}{l}\text { - Adsorbent materials can be regenerated; } \\
\text { - High removal rate, which allows the process to be ap- } \\
\text { plied to any type of biogas use; } \\
\text { - Low operating cost. }\end{array}$ & $\begin{array}{l}\text { - Requires prior removal of particles and oil; } \\
\text { - High investment cost; } \\
\text { - Suitable for small or medium biogas flows. }\end{array}$ \\
\hline Absorption drying & $\begin{array}{l}\text { - Materials can be regenerated; } \\
\text { - High removal rate, which allows the process to be ap- } \\
\text { plied to any type of biogas use; } \\
\text { - Elimination of hydrocarbons particles. }\end{array}$ & $\begin{array}{l}\text { - High investment cost; } \\
\text { - Economic viability only for high biogas flow rates; } \\
\text { - Absorbent material regeneration carried out at } \\
\text { high pressure and temperature. }\end{array}$ \\
\hline
\end{tabular}

Adapted from Silva \& Mezzari [6] and Paterson \& Kuhn [8].

In the condensation drying process, the separation of steam water from biogas takes place through cyclone separators. The biogas pipes can also be cooled below the dew point of the gas, improving the condensation of water. The installation of the pipes is carried out with a slope and a purging system to collect the condensate [8].

In the adsorption drying process, cylindrical reactors containing adsorbent materials are used. The most used is silica gel, but there are others, such as activated carbon, aluminum oxides, magnesium oxides and zeolites. These materials are installed in a fixed bed, which is exchanged and regenerated when saturated. The installation operates alternately with two columns, in one there is adsorption at room temperature and pressure from 6 up to 10 bar, while the saturated column is regenerated [7].

Absorption drying is a process in which biogas flows through an absorption tower, in countercurrent with a solution of glycol or other hygroscopic substances. Water steam, as well as hydrocar- bons and particles, are chemically absorbed. It is a process originally used in the treatment of natural gas. The operation is carried out at high pressure, between 20 and 40 bar, and the regeneration process occurs at temperatures of around $200^{\circ} \mathrm{C}$ [8].

\section{$\mathrm{H}_{2} \mathrm{~S}$ removal process}

$\mathrm{H}_{2} \mathrm{~S}$ removal can be carried out through biological or physical-chemical processes, and can be classified as internal or external, depending on whether they occur inside or outside the anaerobic digester. This process can be divided into two levels, according to the intended application for biogas. In the first level, $\mathrm{H}_{2} \mathrm{~S}$ is reduced to values below $500 \mathrm{ppm}$, reaching in some cases values of approximately $100 \mathrm{ppm}$. The second level allows the $\mathrm{H}_{2} \mathrm{~S}$ concentrations to be reduced to values below $0.005 \mathrm{ppm}$, meeting the specifications and requirements for the use of biomethane [6]. The advantages and disadvantages of each biological and physical-chemical $\mathrm{H}_{2} \mathrm{~S}$ removal processes from biogas are summarized in Table 2 \& 3, respectively. 
Table 2: Advantages and disadvantages of the biological processes used to remove $\mathrm{H}_{2} \mathrm{~S}$ from biogas.

\begin{tabular}{|c|c|c|}
\hline Process & Advantages & Disadvantages \\
\hline In situ & $\begin{array}{l}\text { - Simple process; } \\
\text { - Low investment and maintenance costs; } \\
\text { - Doesn't require the chemicals use. }\end{array}$ & $\begin{array}{l}\text { - Oxygen injection can affect the anaerobic } \\
\text { process, oxidizing } \mathrm{CH}_{4} ; \\
\text { - Potentially explosive mixtures may occur; } \\
\text { - Doesn't allow to achieve the purification } \\
\text { requirements for obtaining biomethane. }\end{array}$ \\
\hline Biofilter & $\begin{array}{l}\text { - Oxygen injection is external to the digester, therefore } \\
\text { without negative influence on the anaerobic process; } \\
\text { - Doesn't require the chemicals use; } \\
\text { - Enables ammonia removal. }\end{array}$ & $\begin{array}{c}\text { - High air injection through the biofilter, not } \\
\text { being suitable for the treatment of biomethane; } \\
\text { - Suitable for small biogas flows; } \\
\text { - Need for extra maintenance to renew nutri- } \\
\text { ents. }\end{array}$ \\
\hline Biological gas scrubber & $\begin{array}{l}\text { - Oxygen injection is external to the digester, therefore } \\
\text { without negative influence on the anaerobic process; } \\
\text { - Allow to achieve the purification requirements for obtain- } \\
\text { ing biomethane; } \\
\text { - Suitable for high biogas flows. }\end{array}$ & $\begin{array}{l}\text { - Requires the chemicals use; } \\
\text { - High maintenance and operating costs; } \\
\text { - Need to introduce fresh water in the process. }\end{array}$ \\
\hline
\end{tabular}

Adapted from Paterson \& Kuhn [7] and Santos \& Joppert [8].

Table 3: Advantages and disadvantages of the physical-chemical processes used to remove $\mathrm{H}_{2} \mathrm{~S}$ from biogas.

\begin{tabular}{|c|c|c|}
\hline Process & Advantages & Disadvantages \\
\hline Addition of salts or iron oxides in situ & $\begin{array}{l}\text { - Simple process with reduced costs; } \\
\text { - Doesn't require oxygen injection; } \\
\text { - Low maintenance. }\end{array}$ & $\begin{array}{l}\text { - Doesn't allow to achieve the purification } \\
\text { requirements for obtaining biomethane; } \\
\text { - Formation of precipitates within the digester } \\
\text { is a potential problem; } \\
\text { - Consumption of chemicals. }\end{array}$ \\
\hline Adsorption & $\begin{array}{l}\text { - Moderate investment costs; } \\
\text { - High removal rate, allowing to achieve the purification } \\
\text { requirements for obtaining biomethane; } \\
\text { - Oxygen injection hasn't negative impact, with the use of } \\
\text { doped activated carbon. }\end{array}$ & $\begin{array}{l}\text { - High energy costs with adsorbent regenera- } \\
\text { tion; } \\
\text { - Need for extra maintenance to renew or } \\
\text { replace the adsorbent; } \\
\text { - Doesn't allow the use of the extracted sulfur. }\end{array}$ \\
\hline
\end{tabular}

Adapted from Silva \& Mezzari [6], Paterson \& Kuhn [7] and Santos \& Joppert [8].

Removal of $\mathrm{H}_{2} \mathrm{~S}$ in situ is a biotechnology that is based on the direct injection of pure air or oxygen. The bacteria that oxidize $\mathrm{H}_{2} \mathrm{~S}$ develop with the presence of $\mathrm{O}_{2}$, occurring the biological removal process of $\mathrm{H}_{2} \mathrm{~S}$, producing sulfur $(\mathrm{S})$ that leaves the digester through the digested. These microorganisms are widely found in the anaerobic environment of biodigesters [7].

The technology through biofilter consists of passing the biogas through a column with synthetic material, forming a biofilm. A parallel or countercurrent flow maintains the conditions of humidity and nutrients, essential for the microorganisms responsible for the degradation of $\mathrm{H}_{2} \mathrm{~S}$ [7].

In biological gas scrubber, the removal of $\mathrm{H}_{2} \mathrm{~S}$ is carried out using a two-stage system. The first stage consists of a $\mathrm{H}_{2} \mathrm{~S}$ scrubbing column, using a sodium hydroxide solution. In the second stage, a column with activated sludge is injected with air, since the microorganisms are aerobic, resulting in the solution regeneration [8].

The addition of salts or iron oxides in situ (or sulfide precipitation) is a physical-chemical where $\mathrm{H}_{2} \mathrm{~S}$ is removed inside the digester during the production of biogas through anaerobic digestion. The salts or iron oxides react with $\mathrm{H}_{2} \mathrm{~S}$, resulting in non-soluble compounds, such as iron sulfides, which precipitate and are removed with the effluents from the digester. The addition is carried out by direct dosing using a reactor installed in the biogas line [6]. The $\mathrm{H}_{2} \mathrm{~S}$ adsorption process is based on its retention in a solid with a large surface area or in materials with high internal porosity. The most widely used adsorbent materials are activated carbon and iron oxides. Activated carbon makes it possible to obtain low concentrations of $\mathrm{H}_{2} \mathrm{~S}$. This process is based on the catalytic oxidation of $\mathrm{H}_{2} \mathrm{~S}$ on the surface of the activated carbon, which can 
be impregnated with catalysts to increase the reaction speed and improve the load capacity [8].

\section{Biogas Upgrading}

The high degree of biogas purification treatment to obtain biomethane requires the use of more complex and expensive techniques, as they allow the removal of contaminants more efficiently. This upgrading is carried out through treatment and purification processes, involving technologies to remove the other gases present in the biogas, separating the $\mathrm{CH}_{4}$ and thus increasing its calorific value [1].

The biogas purification process comprises $\mathrm{CO}_{2}$ removal, which is necessary mainly when the aim is to obtain biomethane for injection into household pipeline system for natural gas distribution or use as a vehicle fuel, fulfilling the standard requirements in each country [3]. The advantages and disadvantages of main biogas purification processes are summarized in Table 4 .

Table 4: Advantages and disadvantages of the biogas purification processes.

\begin{tabular}{|c|c|c|}
\hline Process & Advantages & Disadvantages \\
\hline Pressure Swing Adsorption (PSA) & $\begin{array}{l}\text { - CH4 concentration greater than } 96 \% \text {; } \\
\text { - Allows other impurities removal; } \\
\text { - Low operating costs; } \\
\text { - Adsorbent materials regeneration; } \\
\text { - Suitable for small scale applications. }\end{array}$ & $\begin{array}{l}\text { - High investment cost; } \\
\text { - High } \mathrm{CH}_{4} \text { losses; } \\
\text { - Requires the prior } \mathrm{H}_{2} \mathrm{O} \text { and } \mathrm{H}_{2} \mathrm{~S} \text { removal; } \\
\text { - High electricity consumption; } \\
\text { - Demanding operation control. }\end{array}$ \\
\hline Pressurized water scrubbing & $\begin{array}{l}\text { - Flexible and adjustable process to the } \mathrm{CO} 2 \text { content } \\
\text { present in the biogas; } \\
\text { - } \mathrm{CH}_{4} \text { concentration between } 96 \text { to } 99 \% \text {; } \\
\text { - Allows other impurities removal; } \\
\text { - Continuous and automatic operation. }\end{array}$ & $\begin{array}{l}\text { - High operating costs with water regeneration; } \\
\text { - High water and electricity consumption; } \\
\text { - High } \mathrm{CH}_{4} \text { losses; } \\
\text { - Requires the prior } \mathrm{H}_{2} \mathrm{~S} \text { removal. }\end{array}$ \\
\hline Amine scrubbing & $\begin{array}{l}\text { - Low } \mathrm{CH}_{4} \text { losses, with no need to treat residual gas; } \\
-\mathrm{CH}_{4} \text { concentration greater than } 99 \% \text {; } \\
\text { - It is carried out at atmospheric pressure, with low } \\
\text { electricity consumption. }\end{array}$ & $\begin{array}{l}\text { - High thermal energy consumption; } \\
\text { - Previous H2S removal is recommended, oth- } \\
\text { erwise regeneration requires higher tempera- } \\
\text { tures; } \\
\text { - High operating costs; } \\
\text { - Consumption of chemicals. }\end{array}$ \\
\hline Membrane permeation & $\begin{array}{l}\text { - } \mathrm{CH}_{4} \text { concentration greater than } 96 \% ; \\
\text { - Low investment cost; } \\
\text { - Compact and simple installation system; } \\
\text { - Low maintenance; } \\
\text { - Degree of purity adjustment. }\end{array}$ & $\begin{array}{l}\text { - Previous } \mathrm{H}_{2} \mathrm{~S} \text { and } \mathrm{H}_{2} \mathrm{O} \text { removal is recommend- } \\
\text { ed, protecting membrane performance; } \\
\text { - High electricity consumption; } \\
\text { - High } \mathrm{CH}_{4} \text { losses; } \\
\text { - Significant operating costs. }\end{array}$ \\
\hline
\end{tabular}

Adapted from Khan et al. [1], Rafiee et al. [3] and Santos \& Joppert [7].

\section{Adsorption process}

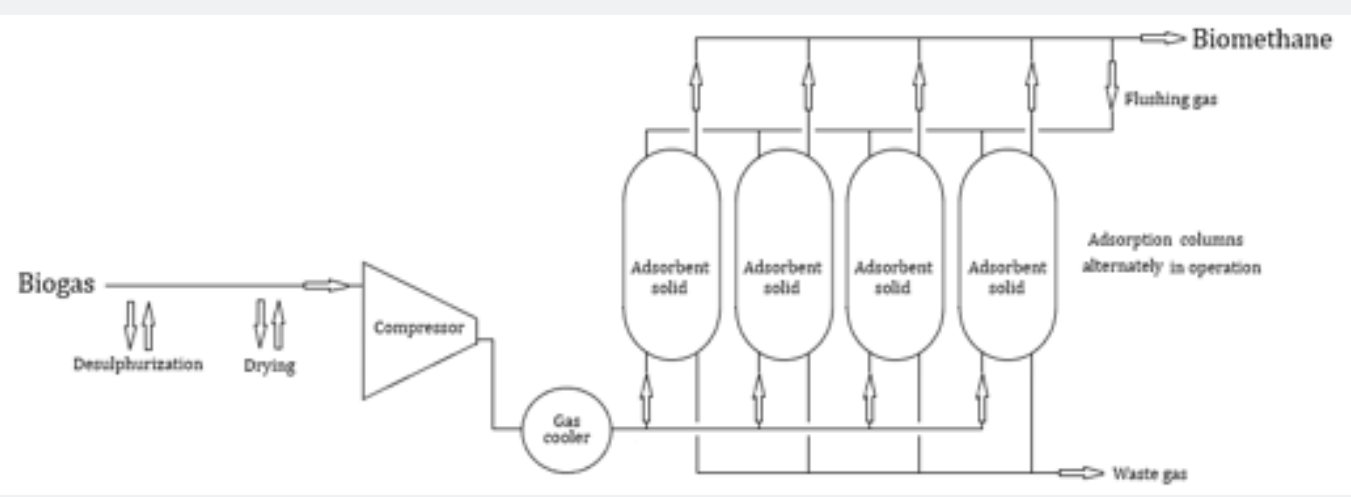

Figure 3: Biogas purification using PSA. 
The $\mathrm{CO}_{2}$ adsorption process in adsorbent solids such as zeolite, activated carbon, silica or alumina, to physical separation of biogas, constitutes the Pressure Swing Adsorption (PSA). This process (Figure 3 ) is based on $\mathrm{CO}_{2}$ ability to be adsorbed at high pressures, and the ability to be desorbed at low pressures. For this purpose, parallel adsorption columns are used, in which, alternately and after regeneration, starts a new cycle. To avoid an efficiency reduction of the process, biogas components, such as $\mathrm{H}_{2} \mathrm{O}$ and $\mathrm{H}_{2} \mathrm{~S}$, must be previously removed because they are irre- versibly adsorbed on the adsorbent solids. However, other contaminants present in biogas, such as $\mathrm{N}_{2}$ and $\mathrm{O}_{2}$, can be removed through this process [1].

\section{Absorption processes}

The $\mathrm{CO}_{2}$ absorption process depends on the biogas components solubility, when passing in countercurrent with a liquid solvent, through a column that increases the contact area between the biogas and the liquid [3].

\section{Pressurized water scrubbing}

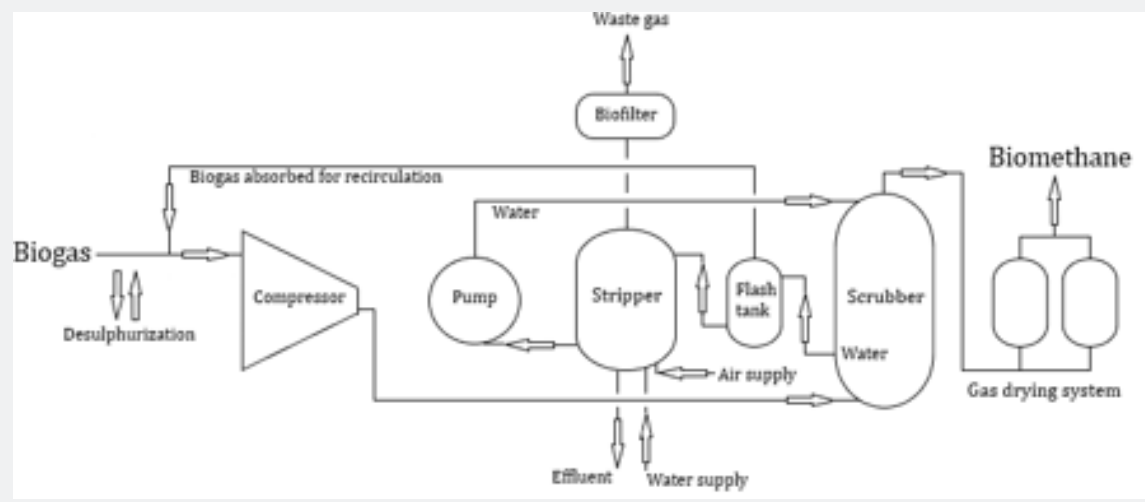

Figure 4: Biogas purification using pressurized water scrubbing.

Pressurized water scrubbing is based on the fact that $\mathrm{CO}_{2}$ has greater solubility in water, compared to $\mathrm{CH}_{4}$ [3]. This process is simple and is the most popular biogas upgrading process (Figure 4). The $\mathrm{H}_{2} \mathrm{~S}$ present in biogas has high water solubility, and its removal is difficult. Thus, it is necessary to previously remove $\mathrm{H}_{2} \mathrm{~S}$ from biogas, avoiding corrosion problems and decreasing the efficiency of the process. The biogas is initially compressed and is then fed to the absorption column (scrubber), where the cooled $\left(5^{\circ} \mathrm{C}\right)$ and pressurized (4-10 bar) water absorbs $\mathrm{CO}_{2}$ and other impurities. The water regeneration is carried out, in a first phase (flash tank), with the recovery of the absorbed biogas, being recycled through the injection at the biogas inlet. The second phase of regeneration takes place in a second column (stripper) through a countercurrent with air, operating under atmospheric pressure [1].

\section{Amine scrubbing}

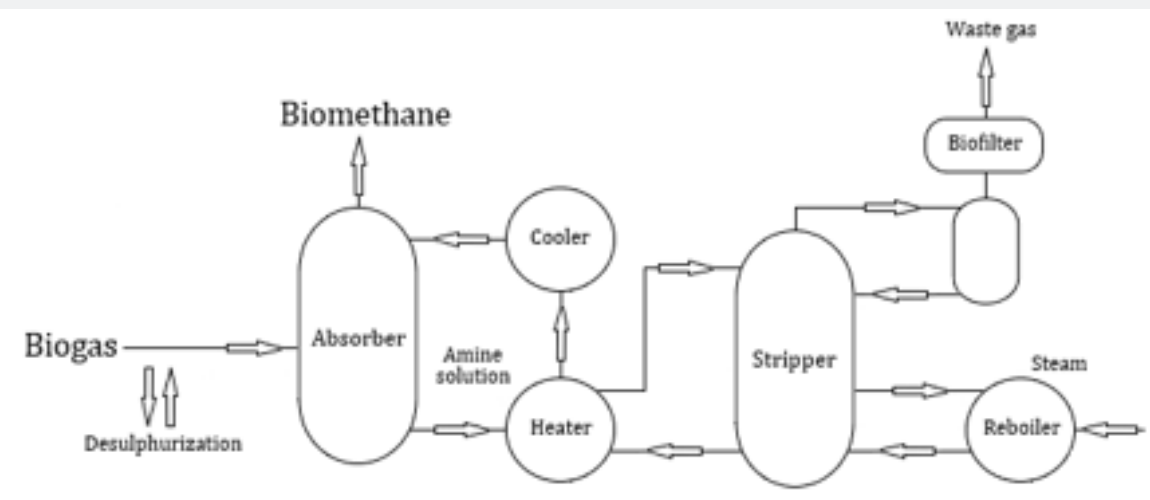

Figure 5: Biogas purification using amine scrubbing.

This process is similar to pressurized water scrubbing and is a chemical absorption technique where the solution absorbs the $\mathrm{CO}_{2}$ present in the biogas, through a chemical reaction between the amine and $\mathrm{CO}_{2}$ (Figure 5). The absorber operates at 1-2 bar while the operating pressure of the stripper is usually 1.5-3 bar. The reaction is exothermic, causing an increase in temperature in the amine solution, with $\mathrm{CO}_{2}$ being absorbed with high efficiency, since the reaction rate between $\mathrm{CO}_{2}$ and the amine solution 
increases with increasing temperature. To avoid poisoning the amine it is necessary to remove the $\mathrm{H}_{2} \mathrm{~S}$ from the biogas before the process. In the solution regeneration, steam is normally used [7].

\section{Membrane permeation}

The membrane permeation technique is based on the difference in permeability of the different constituents of biogas (Figure 6). The gases separation occurs through the action of a membrane. While $\mathrm{CH}_{4}$ is retained, the remaining constituents, mainly $\mathrm{CO}_{2}$, penetrate through the membrane, causing separation. Currently, three different types of membranes are used for biogas purification: polymeric, inorganic and mixed matrix membranes. In this process, $\mathrm{H}_{2} \mathrm{~S}$ and $\mathrm{H}_{2} \mathrm{O}$ removal isn't necessary, however, it is recommended not to affect the membrane performance. The introduction of several stages of membranes promises to solve this problem, producing biomethane with $\mathrm{CH}_{4}$ concentration above 98\% and with low operational cost [3].

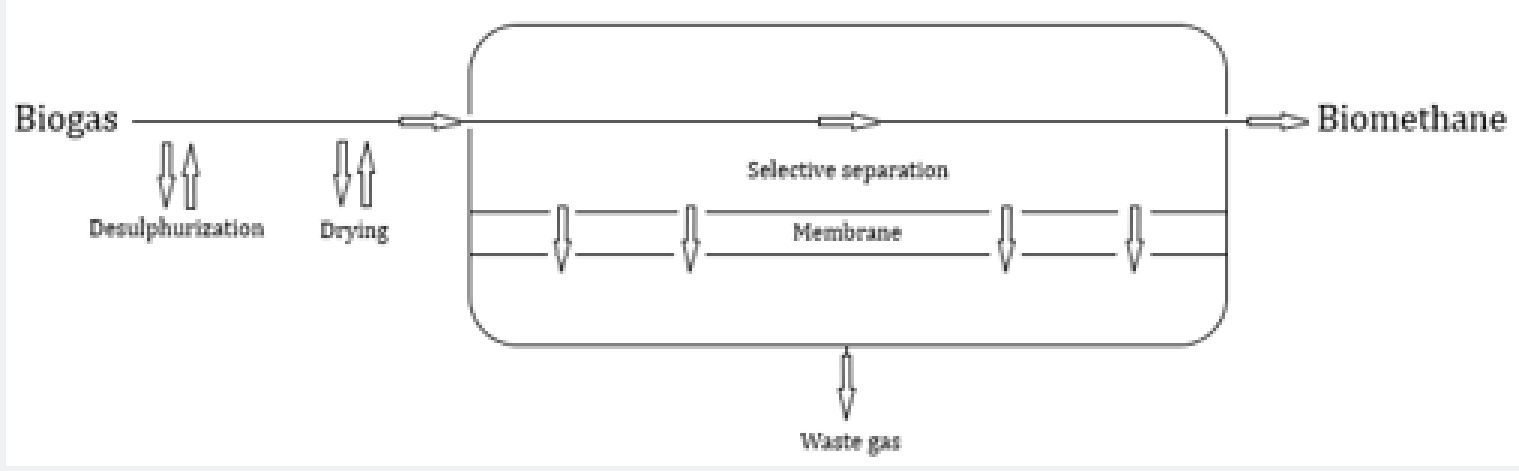

Figure 6: Biogas purification using membrane permeation.

\section{Emerging technologies}

Without application on an industrial scale, other emerging techniques currently under development, promise effective results in the biogas purification.

Cryogenic separation is a suitable solution to produce liquefied biomethane, where different gases liquefy under different pressure and temperature conditions. The previously dried and desulphurized biogas is subjected to a compression and cooling process, where $\mathrm{CO}_{2}$ liquefies first, in three successive stages of temperature, since it has a boiling point higher than $\mathrm{CH}_{4}$. Thus, it is possible to separate these two gases. This process requires the use of various devices and equipment, making it an expensive option [7].

Temperature Swing Adsorption (TSA) is also a recent technique and consists of operating with temperature variation, instead of using pressure variation as in pressure swing adsorption. Through lower temperatures, the adsorption process becomes more effective, with regeneration taking place with increasing temperature [7].

Another alternative and innovative solution is the biological method via hydrogenotrophic methanogenesis, which occurs through the action of hydrogenotrophic methanogenic microorganisms during the production of biogas by anaerobic digestion. $\mathrm{CO}_{2}$ and $\mathrm{H}_{2}$ are converted biologically to $\mathrm{CH}_{4}$, without the need for additional energy, resulting in a concentration of $\mathrm{CH}_{4}$ in the biogas greater than $98 \%$. However, this biological process has limitations concerning its commercial application, such as the increasing $\mathrm{pH}$ of the digester as well as requiring the introduction of $\mathrm{H}_{2}$ into the system [3].

\section{Conclusion}

It is estimated that biogas will play an important role in the renewable energy development market. In this context, treatment and purification technologies are important, enabling the elimination of impurities from biogas, as well as the obtaining of biomethane. Worldwide, the use of biomethane as a vehicle fuel is expected to rise from a current value of $2 \%$ to $27 \%$ in 2050 [3]. The use of biomethane in the coming decades is also strongly aimed at applications where electrification is not possible in the short term, such as heavy industry, long-distance transport and aviation [9]. The growing perspective of the biomethane injection into household pipeline system for natural gas distribution, assumes that the biogas production and purification facilities for biomethane must be located close to this infrastructure [10].

Biological techniques are in sharp growth, due to their low cost and increasing efficiency of $\mathrm{H}_{2} \mathrm{~S}$ removal, but currently the market is dominated by physical-chemical technologies. The $\mathrm{H}_{2} \mathrm{~S}$ adsorption on activated carbon is the most used process to remove $\mathrm{H}_{2} \mathrm{~S}$ in biogas. The process of adding salts or iron oxides in situ is normally used when the application of biogas is intended to produce heat in boilers. Biofilters are commonly used to remove $\mathrm{H}_{2} \mathrm{~S}$ before CHP units for the production heat and electricity. To obtain very low levels of $\mathrm{H}_{2} \mathrm{~S}$, with high purification of biogas to biomethane, the $\mathrm{H}_{2} \mathrm{~S}$ removal is usually combined with the $\mathrm{CO}_{2}$ removal process [7]. The commercially available technologies for biogas purification are primarily indicated for $\mathrm{CO}_{2}$ removal, but they also 
allow the removal of other impurities. The most used technique to remove $\mathrm{CO}_{2}$ from biogas is pressurized water scrubbing. Amine absorption has been growing in recent years, preferably for smaller biogas flows and in places with cheap heat sources. In recent years, membrane permeation has grown, due to the availability of highly selective and low-cost polymeric materials [3]. The project-specific circumstances and raw biogas capacity significantly influence the costs of different purification technologies [1].

Currently, there are systems that allow the use of removed $\mathrm{CO}_{2}$ in other processes, reinforcing the sustainability of biogas production and the concept of circular bioeconomy. The innovative biomethanol production systems integrated with biogas production and purification units are an example of this. The $\mathrm{CO}_{2}$ resulting from the $\mathrm{CH}_{4}$ separation from biogas, (together with $\mathrm{H}_{2}$, produced by electrolysis through electricity from renewable sources) are the raw materials to produce renewable methanol in a biogas plant [11].

\section{Acknowledgement}

This work was financially supported by: Base Funding UIDB/50020/2020 of the Associate Laboratory LSRE-LCM - funded by national funds through FCT/MCTES (PIDDAC).

\section{Conflict of Interest}

All authors of this review Paulo S. Domingues, Helena Sousa and Nelson S. Oliveira declares that they have no conflict of interest.

\section{References}

1. Rafiee A, Khalilpour K, Prest J, Skryabin I (2021) Biogas as an energy vector. Biomass and Energy 144: 105935.
2. Kadam R, Panwar N (2017) Recent advancement in biogas enrichment and its applications. Renewable and Sustainable Energy Reviews 73: 892-894.

3. Khan IU, Othman MH, Hashim H, Matsuura T, Ismail A, et al. (2017) Biogas as a renewable energy fuel - A review of biogas upgrading, utilisation and storage. Energy Conversion and Management 150: 277291.

4. Tabatabaei M, Aghbashlo M, Valijanian E, Panahi H, Nizami AS, et al. (2019) A comprehensive review on recent biological innovations to improve biogas production, Part 2: Mainstream and downstream strategies. Renewable Energy 146: 1392-1407.

5. Neshat SA, Mohammadi M, Najafpour GD, Lahijani P (2017) Anaerobic co-digestion of animal manures and lignocellulosic residues as a potent approach for sustainable biogas production. Renewable and Sustainable Energy Reviews 79: 308-322.

6. Silva ML, Mezzari MP (2019) Tratamento e purificação de biogás - Capítulo IV. In: Kunz A, Steinmetz RLR, Amaral AC (Eds.), do Fundamentos da digestão anaeróbia, purificação do biogás, uso e tratamento do digestato. Embrapa, pp. 70-89.

7. Santos MM, Joppert CL (2018) Biometano (Parte II). In: Coelho ST (Ed.), Tecnologias de produção e uso de biogás e biometano. Instituto de Energia e Ambiente/USP/Synergia, pp. 117-159.

8. Mark P; Werner FNRK (2010) Guia Prático do Biogás. Geração e Utilização, pp. 115-124.

9. Simon F (2019) The future of biogas in Europe: it's a local affair.

10. Turmes C (2018) The future of gas is not fossil but green.

11. Eggemann L, Escobar N, Peters R, Burauel P, Stolten D (2020) Life cycle assessment of a small-scale methanol production system: A Powerto-Fuel strategy for biogas plants. Journal of Cleaner Production 271: 122476.
Your next submission with Juniper Publishers will reach you the below assets

- Quality Editorial service

- Swift Peer Review

- Reprints availability

- E-prints Service

- Manuscript Podcast for convenient understanding

- Global attainment for your research

- Manuscript accessibility in different formats ( Pdf, E-pub, Full Text, Audio)

- Unceasing customer service

Track the below URL for one-step submission https://juniperpublishers.com/online-submission.php 